\title{
PERAN KOMUNIKASI DAN POLA ASUH ORANGTUA TERHADAP PERILAKU SEKSUAL SISWA SEKOLAH MENENGAH PERTAMA DI KECAMATAN SUKORAMBI KABUPATEN JEMBER
}

\section{The Role of Communication and Parenting Style to Sexual Behavior Among Junior High School Student in Sukorambi Sub District, Jember Regency}

\author{
Holfi Mariyatul Kiptiyah, Ni'mal Baroya* \\ Peminatan Biostatistika dan Kependudukan Fakultas Kesehatan Masyarakat, Fakultas Kesahatan \\ Masyarakat, Universitas Jember \\ *email: nbaroya@unej.ac.id
}

\begin{abstract}
Risk sexual behavior in adolescents when dating was an effect of the role of parents. The presence of parents through effective communication and proper parenting was expected to be able to cope with increased risky sexual behavior in adolescents. This study aims to analyze the relationship between the role of communication and parenting style with risky sexual behavior in students in one junior high school in Sukorambi, Jember Regency. This research was an observational analytic study with cross sectional design. The subjects of this study were 101 students who stated that they had/were dating. Data was collected using questionnaires by respondents. The collected data were analyzed using the Chi Square test with a significance value of $\alpha=0.05$. The results showed the sexual behavior of adolescents when dating was included in the high risk category, namely to the stage of attaching genitals with limited clothing. Most parents communicate functionally with teenagers, but do not communicate about sexuality. Most teenagers get authoritative parenting. Female students and students aged > 15 years are more at risk of high risk sexual behavior when dating. Students who state that their parents communicate dysfunctionally and do not discuss sexuality with teens are more at risk of high-risk sexual behavior. Adolescents who get authoritarian and permissive parenting are more at risk of high risk sexual behavior than adolescents who get authoritative / democratic parenting. Provision of material on teenage sexuality to parents is important so that parents are able to communicate effectively with teens.
\end{abstract}

Keywords: teenagers, sexual behavior, parenting style, communication

\begin{abstract}
Abstrak
Perilaku seksual berisiko pada remaja saat berpacaran merupakan efek dari peran orangtua. Kehadiran orangtua melalui komunikasi efektif dan pola asuh yang tepat diharapkan dapat mengatasi meningkatnya perilaku seksual berisiko pada remaja. Penelitian ini bertujuan untuk menganalisis hubungan peran komunikasi dan pola asuh orangtua dengan perilaku seksual berisiko pada siswa di salah satu sekolah menengah pertama di Sukorambi Kabupaten Jember. Penelitian ini merupakan studi analitik observasional dengan desain cross sectional. Subjek penelitian ini berjumlah 101 siswa yang menyatakan pernah/sedang berpacaran. Data dikumpulkan menggunakan pengisian kuesioner oleh responden. Data yang sudah terkumpul dianalisis menggunakan uji Chi Square dengan nilai signifikansi $\alpha=0.05$. Hasil penelitian menunjukkan perilaku seksual remaja saat berpacaran sudah termasuk kategori berisiko tinggi yaitu sampai tahap melakukan petting. Sebagian besar responden menyatakan orangtua mereka melakukan komunikasi yang bersifat fungsional dengan remaja, namun tidak melakukan komunikasi tentang seksualitas. Sebagian besar remaja mendapatkan pola asuh autoritatif. Siswa perempuan dan siswa yang berusia $>15$ tahun lebih berisiko berperilaku sexual risiko tinggi saat berpacaran. Siswa yang menyatakan orangtuanya berkomunikasi secara disfungsional dan tidak membicarakan seksualitas dengan remaja lebih berisiko berperilaku seksual risiko tinggi. Remaja yang mendapat pola asuh autoritarian dan permisif lebih berisiko berperilaku seksual risiko tinggi dibandingkan remaja yang mendapatkan pola asuh autoritatif/demokratis. Pemberian materi tentang
\end{abstract}


seksualitas remaja kepada orang tua menjadi penting agar orang tua mampu berkomunikasi efektif dengan remaja.

Kata kunci: remaja, perilaku seksual, pola asuh orangtua, komunikasi

\section{PENDAHULUAN}

Masa remaja erat kaitannya dengan masa berfantasi seksual dan menjadikan seksualitas sebagai bagian dari identitasnya (Santrock, 2003). Hal tersebut menjadikan remaja tidak terlepas dari permasalahan kesehatan reproduksi remaja. Pengalaman seksual di kalangan remaja biasanya terjadi saat remaja berpacaran (SDKI, 2013). Aktivitas seksual yang dilakukan saat berpacaran remaja saat ini sangat mengkhawatirkan karena bersifat meningkat atau progresif. Survei Kesehatan Reproduksi Remaja Indonesia tahun 2012 melaporkan bahwa usia pertama kali berpacaran remaja sebelum usia 15 tahun meningkat dari tahun sebelumnya, sebanyak $27 \%$ pada wanita dan 28\% pada laki-laki (SDKI, 2013). Hasil Survei Nasional Kesehatan Berbasis Sekolah di Indonesia menyebutkan proporsi pelajar yang melakukan hubungan intim sebesar $6,17 \%$ dan umur pertama kali melakukan hubungan intim $0,78 \%$ pada umur 11 tahun atau lebih muda (Kusmawardani et al., 2015). Aktivitas seksual yang dilakukan pada usia remaja memiliki risiko tinggi bagi kesehatan reproduksi remaja. Remaja menyumbang $30 \%$ pada kasus Kehamilan Tidak Diinginkan (KTD) dan aborsi tidak aman. Remaja usia 15-19 tahun berhenti sekolah dengan alasan hamil sebanyak 0,4\% atau 836 anak di Indonesia (SDKI, 2013).

Faktor yang dapat mempengaruhi perilaku seksual remaja yaitu kurangnya pengetahuan mengenai kesehatan reproduksi (Sarwono, 2006). Pengetahuan remaja tentang kesehatan reproduksi belum memadai. Hanya $35 \%$ remaja wanita dan 31,1\% remaja laki-laki usia 15-19 tahun yang mengetahui bahwa wanita dapat hamil dengan satu kali berhubungan seksual. Empat puluh lima persen remaja mendapat informasi kesehatan reproduksi dari teman sekolah, 16,3\% dari guru, 12,8\% dari petugas kesehatan, $8,7 \%$ dari orangtua dan 6,8\% dari tokoh agama (Suwandono, 2006). Hanya sebagian kecil remaja yang mendapatkan pengetahuan dari orangtua. Orangtua seharusnya menjadi informan utama bagi remaja melalui komunikasi yang efektif dan pola asuh yang tepat, namun kenyataannya komunikasi orangtua dengan remaja dalam membicarakan kesehatan reproduksi dan permasalahan yang dihadapi remaja masih sangat rendah (Suwarni, 2009).

Badan Koordinasi Keluarga Berencana Nasional (BKKBN) melalui Organisasi Pemerintah Daerah bidang Keluarga Berencana melaksanakan program Bina Keluarga Remaja (BKR). Program BKR bertujuan untuk meningkatkan pengetahuan dan keterampilan keluarga dalam mengasuh dan membina tumbuh kembang remaja melalui peran orangtua dalam keluarga, sehingga diharapkan dapat mengatasi meningkatnya kecenderungan perilaku seks bebas dikalangan remaja. Namun Berdasarkan Laporan dari DP3AKB Kabupaten Jember tahun 2016 capaian keikutsertaan anggota BKR tahun 2016 masih sangat rendah yaitu hanya $3,26 \%$. Salah satu wilayah dengan capaian keikutsertaan anggota BKR terendah yaitu Kecamatan Sukorambi yang hanya mencapai 2,88\%. Diantara wilayah yang memiliki capaian BKR terendah, kecamatan Sukorambi yang tercatat sebagai wilayah dengan angka rasio beban tanggungan (Dependency ratio) sebesar 47,89\%. Angka tersebut menyatakan bahwa sebagian besar penduduk di Kecamatan Sukorambi adalah berusia muda (0-14 tahun) (Rokhmah, 2014). Hasil studi pendahuluan yang dilakukan di sekolah menengah pertama di Kecamatan Sukorambi ditemukan 59\% remaja mengaku telah berpacaran sehingga remaja berpotensi melakukan perilaku seksual yang berisiko.

Penelitian ini bertujuan untuk menganalisis hubungan peran komunikasi dan pola asuh orangtua terhadap perilaku seksual berisiko tinggi pada siswa berpacaran di sekolah menengah pertama di Kecamatan Sukorambi Kabupaten Jember. Hasil penelitian ini dapat memperkuat bukti ilmiah tentang pentingnya kehadiran orang tua dalam pertumbuhan dan perkembangan remaja

\section{METODE PENELITIAN}

Penelitian ini merupakan jenis studi analitik dengan desain penelitian cross sectional. Penelitian dilakukan di salah satu sekolah menengah pertama di Kecamatan Sukorambi Kabupaten Jember tahun 2017. Populasi pada penelitian ini adalah seluruh siwa SMP Sukorambi yang mengaku pernah atau 
sedang berpacaran saat dilakukan penelitian yaitu sebanyak 555 anak. Besar sampel dihitung menggunakan rumus proporsi binomunal (binomunal proportion) sehingga diperoleh sampel sebanyak 101 siswa SMP. Sampel penelitian diambil dengan proportionate stratified random sampling. Instrumen penelitian menggunakan angket yang berisi pertanyaan tertutup dan daftar cocok (ceklist) yang diisi sendiri oleh responden. Data hasil penelitian dianalisis secara bivariabel menggunakan uji Chi-square dengan signifikansi $(\alpha=0.05)$ menggunakan program komputer pengolah data.

\section{HASIL DAN PEMBAHASAN}

\section{Hasil}

Gambaran Karakteristik Individu dan Perilaku Seksual Responden

Hasil penelitian menunjukkan bahwa proporsi responden laki-laki lebih banyak dibandingkan responden perempuan (berturutturut $55,4 \%$ dan 44,6\%). Proporsi responden berumur <15 tahun juga lebih banyak dibandingkan dengan responden berumur $>15$ tahun (berturut-turut 58,4\% dan 41,6\%). Sebagian besar responden tinggal dengan kedua orangtuanya dalam struktur keluarga utuh $(77,2 \%)$.

Mayoritas responden berpacaran pertama kali saat berumur $<15$ tahun (95\%) dengan lama berpacaran $<1$ tahun $(89,1 \%)$. Mayoritas responden mengaku pada saat berpacaran yaitu berpegangan tangan $(93,1 \%)$ dan saling berpandangan $(90,1 \%)$ adapun perilaku tersebut tergolong perilaku seksual berisiko rendah. Sedangkan pada perilaku berisiko tinggi paling banyak responden mengaku pernah berpelukan $(58,4 \%)$ saat berpacaran. Sebagian besar perilaku seksual responden saat berpacaran dikategorikan berperilaku seksual berisiko tinggi sebanyak $(67,3 \%)$ sedangkan responden yang berpacaran dikategorigan berperilaku seksual berisiko rendah hanya $(32,7 \%)$. Dari hasil tersebut dapat disimpulkan bahwa sebagian besar responden yang pernah atau sedang berpacaran di sekolah menengah pertama di Kecamatan Sukorambi tergolong berperilaku seksual yang berisiko tinggi sampai tahap saling menempelkan alat kelamin dengan dibatasi pakaian..

Tabel 1. Hubungan Karakteristik Individu dengan Perilaku Seksual Berisiko Siswa SMP

\begin{tabular}{|c|c|c|c|c|c|c|c|c|}
\hline \multirow{3}{*}{$\begin{array}{l}\text { Karakteristik } \\
\text { Responden }\end{array}$} & \multicolumn{4}{|c|}{ Perilaku Seksual } & \multirow{2}{*}{\multicolumn{2}{|c|}{ Total }} & \multirow{3}{*}{$\begin{array}{c}p- \\
\text { value }\end{array}$} & \multirow{3}{*}{ OR $(95 \%$ CI $)$} \\
\hline & \multicolumn{2}{|c|}{$\begin{array}{l}\text { Berisiko } \\
\text { Tinggi }\end{array}$} & \multicolumn{2}{|c|}{$\begin{array}{l}\text { Berisiko } \\
\text { Rendah }\end{array}$} & & & & \\
\hline & $\mathrm{n}$ & $\%$ & $\mathrm{n}$ & $\%$ & $\mathrm{n}$ & $\%$ & & \\
\hline \multicolumn{9}{|l|}{ Jenis Kelamin } \\
\hline Laki-laki & 33 & 32,7 & 23 & 22,8 & 56 & 55,4 & \multirow[t]{2}{*}{$0,045^{*}$} & 1 \\
\hline Perempuan & 35 & 34,7 & 10 & 9,9 & 45 & 44,6 & & $2,349(1,010-5,891)$ \\
\hline \multicolumn{9}{|l|}{ Umur } \\
\hline$<15$ tahun & 35 & 34,7 & 24 & 23,8 & 59 & 58,4 & \multirow[t]{2}{*}{$0,042 *$} & 1 \\
\hline$\geq 15$ tahun & 33 & 32,7 & 9 & 8,9 & 42 & 41,6 & & $2,514(1,021-6,195)$ \\
\hline \multicolumn{9}{|l|}{ Tinggal Bersama } \\
\hline \multicolumn{9}{|l|}{ Orangtua } \\
\hline Tidak keduanya & 3 & 3,0 & 0 & 0 & 3 & 3 & 0,225 & $1,500(1,282-1,755)$ \\
\hline Salah satunya & 13 & 12,9 & 7 & 6,9 & 20 & 19,8 & \multirow[t]{2}{*}{0,888} & $0.929(0,331-2,607)$ \\
\hline Keduanya & 52 & 51,5 & 26 & 25,7 & 78 & 77,2 & & 1 \\
\hline \multicolumn{9}{|l|}{ Struktur Keluarga } \\
\hline Tidak lengkap & 16 & 15,8 & 7 & 6,9 & 23 & 22,8 & \multirow[t]{2}{*}{0,795} & $1,143(0,418-3,123)$ \\
\hline Lengkap & 52 & 51,5 & 26 & 25,7 & 78 & 77,2 & & 1 \\
\hline \multicolumn{9}{|l|}{$\begin{array}{l}\text { Umur Pertama kali } \\
\text { pacaran }\end{array}$} \\
\hline$<15$ tahun & 65 & 64,4 & 31 & 30,7 & 96 & 95 & \multirow[t]{2}{*}{0,720} & $1,398(0,222-8,798)$ \\
\hline$\geq 15$ tahun & 3 & 3,0 & 2 & 2,0 & 5 & 5 & & 1 \\
\hline \multicolumn{9}{|l|}{ Lama Berpacaran } \\
\hline$\geq 1$ tahun & 10 & 9,9 & 1 & 1 & 11 & 10,9 & \multirow[t]{2}{*}{0,077} & $5,517(0,675-45,075)$ \\
\hline$<1$ tahun & 58 & 57,4 & 32 & 31,7 & 90 & 89,1 & & 1 \\
\hline
\end{tabular}

* Signifikan pada $\alpha<0.05$, dengan menggunakan uji Chi Square 
Hubungan Karakteristik Individu dengan Perilaku Seksual Berisiko

Hasil analisis bivariabel menggunakan uji chi-square sebagaimana disajikan dalam Tabel 1. menunjukkan bahwa tidak terdapat hubungan yang signifikan antara tinggal bersama orangtua $(\mathrm{p}=0,225$ dan 0,888), struktur keluarga $(\mathrm{p}=0.795)$, umur pertama kali pacaran $(\mathrm{p}=0.720)$, dan lama berpacaran $(\mathrm{p}=0,077)$ dengan perilaku seksual berisiko pada siswa saat berpacaran. Hanya jenis kelamin $(\mathrm{p}=0,045)$ dan umur $(\mathrm{p}=0,042)$ yang berhubungan signifikan dengan perilaku seksual. Berdasarkan hasil penghitungan Odds Ratio (OR) diketahui bahwa responden perempuan lebih berisiko 2,2 kali lebih besar berperilaku seksual berisiko saat berpacaran dibandingkan responden laki-laki. Responden yang berumur > 15 tahun berisiko 2,5 kali lebih besar melakukan perilaku seksual yang berisiko dibandingkan yang berumur $<15$ tahun.

\section{Hubungan antara Komunikasi Orangtua dengan Perilaku Seksual Berisiko \\ Dalam artikel ini komunkasi orangtua} dibagi menjadi dua yaitu komunikasi secara umum dan komunikasi seksual. Berdasarkan komunikasi secara umum sebagian responden menyatakan orangtuanya melakukan komunikasi yang bersifat fungsional dengan responden $(72,3 \%)$. Adapun orangtua yang melakukan komunikasi disfungsional hanya
(27,7\%). Sedangkan berdasarkan komunikasi seksual sebagian besar responden menyatakan orangtua mereka tidak melakukan komunikasi tentang seksualitas $(71,3 \%)$ dan yang terbiasa melakukan hanya $(28,7 \%)$. Topik seksualitas yang sering dibicarakan orangtua dengan responden adalah ciri-ciri pubertas $(58,4 \%)$, narkoba (47,5\%), menstruasi $(39,6 \%)$ dan mimpi basah $(21,8 \%)$. Alasan tidak melakukan komunikasi seksual paling banyak responden mengaku merasa malu $(58,4 \%)$ dan takut dimarahi $(48,5 \%)$.

Hasil analisis bivariabel menggunakan uji chi-square sebagaimana disajikan dalam Tabel 2. menunjukkan bahwa ada hubungan yang signifikan antara komunikasi secara umum $(\mathrm{p}=0,000)$ dan komunikasi seksual $(\mathrm{p}=0,000)$ dengan perilaku seksual responden saat berpacaran. Berdasarkan hasil penghitungan Odds Ratio (OR) diketahui bahwa responden yang melakukan komunikasi bersifat disfungsional dengan orangtuanya cenderung melakukan perilaku seksual berisiko tinggi sebesar 1,7 kali lebih besar dibandingkan dengan responden yang melakukan komunikasi bersifat fungsional. Begitu pula dengan responden yang tidak melakukan komunikasi seksual dengan orangtuanya cenderung melakukan perilaku seksual berisiko tinggi sebesar 3,882 dibandingkan dengan responden yang melakukan komunikasi seksual dengan orangtuanya.

Tabel 2. Hubungan komunikasi Orangtua dengan Perilaku Seksual Siswa SMP

\begin{tabular}{|c|c|c|c|c|c|c|c|c|}
\hline \multirow{3}{*}{$\begin{array}{l}\text { Komunikasi Orangtua } \\
\text { dengan Responden }\end{array}$} & \multicolumn{4}{|c|}{ Perilaku Seksual } & \multirow{2}{*}{\multicolumn{2}{|c|}{ Total }} & \multirow{3}{*}{$p$-Value } & \multirow{3}{*}{ OR $(95 \% \mathrm{CI})$} \\
\hline & \multicolumn{2}{|c|}{$\begin{array}{c}\text { Berisiko } \\
\text { Tinggi }\end{array}$} & \multicolumn{2}{|c|}{$\begin{array}{l}\text { Berisiko } \\
\text { Rendah }\end{array}$} & & & & \\
\hline & $\mathbf{n}$ & $\%$ & $\mathbf{n}$ & $\%$ & $\mathrm{n}$ & $\%$ & & \\
\hline $\begin{array}{l}\text { Komunikasi secara } \\
\text { umum }\end{array}$ & & & & & & & $0,000^{*}$ & \\
\hline Fungsional & 40 & 39,6 & 33 & 32,7 & 73 & 72,3 & & $0,588(0,482-0,718)$ \\
\hline Disfungsional & 28 & 27,7 & 0 & 0 & 28 & 27,7 & & 1 \\
\hline Komunikasi seksualitas & & & & & & & $0,000 *$ & \\
\hline Melakukan & 4 & 4,0 & 25 & 24,8 & 29 & 28,7 & & 1 \\
\hline Tidak melakukan & 64 & 63,4 & 8 & 7,9 & 72 & 71,3 & & $3,882(2,118-7,117)$ \\
\hline
\end{tabular}

* Signifikan pada $\alpha<0.05$, dengan menggunakan uji Chi Square

Tabel 3. Hubungan Pola Asuh Orangtua dengan Perilaku Seksual Siswa SMP

\begin{tabular}{|c|c|c|c|c|c|c|}
\hline \multirow{3}{*}{ Pola Asuh } & \multicolumn{4}{|c|}{ Perilaku Seksual } & \multirow{3}{*}{ p-value } & \multirow{3}{*}{ OR $(95 \% \mathrm{CI})$} \\
\hline & \multicolumn{2}{|c|}{ Berisiko Tinggi } & \multicolumn{2}{|c|}{ Berisiko Rendah } & & \\
\hline & $\mathbf{n}$ & $\%$ & $\mathbf{n}$ & $\%$ & & \\
\hline Autoritatif & 28 & 27,7 & 28 & 27,7 & 1 & 1 \\
\hline Autoritharian & 31 & 30,7 & 4 & 4,0 & $0,000 *$ & $(2,416-24,861)$ \\
\hline Permisif & 9 & 8,9 & 1 & 1,0 & $0,034 *$ & $(1,068-75,837)$ \\
\hline
\end{tabular}

* Signifikan pada $\alpha<0.05$, dengan menggunakan uji Chi Square 
Hubungan Pola Asuh Orangtua dengan
Perilaku Seksual Remaja
Tabel 3. menunjukkan bahwa, sebagaian besar responden mendapatkan pola asuh autoritatif $(55,4 \%)$ yaitu pola asuh yang mendorong responden untuk bebas tetapi tetap memberikan batasan dan dapat mengendalikan tindakan-tindakan mereka. Adapun proporsi responden dengan pola asuh autoritharian adalah $34,7 \%$ dan pola asuh permisif $9,9 \%$. Hasil analisis bivariabel menggunakan uji chisquare dapat diketahui terdapat hubungan yang signifikan antara pola asuh authoritatif $(\mathrm{p}=0,000)$ dan pola asuh permisif $(\mathrm{p}=0,034)$ dengan perilaku seksual berisiko tinggi pada remaja berpacaran. Berdasarkan nilai Odds Ratio (OR) diketahui responden yang mendapat pola asuh autoritharian/otoriter cenderung berperilaku seksual berisiko 7,75 kali lebih besar dibandingkan dengan responden yang menerima pola asuh autoritatif/demokratis. Responden yang mendapat pola asuh permisif/longgar cenderung melakukan perilaku seksual berisiko 9 kali lebih besar dibandingkan dengan responden yang menerima pola asuh autoritatif/demokratis.

\section{Pembahasan}

\section{Hubungan Karaktersitik Individu dengan Perilaku Seksual Berisiko}

Pada karakteristik remaja terdapat dua variabel yang memiliki hubungan signifikan dengan perilaku seksual saat berpacaran yaitu jenis kelamin dan umur. Remaja perempuan lebih berisiko berperilaku seksual berisiko tinggi dibandingkan remaja. Hasil penelitian ini memperkuat penelitian sebelumnya yang menyatakan bahwa frekuensi remaja yang mengaku telah melakukan hubungan seksual sebagian besar terjadi pada remaja perempuan (Nurhayati, 2013). Jenis kelamin akan menentukan bagaimana respon remaja dalam memasuki masa pubertas baik secara fisik, emosional, dan sosial. Hasil studi di Texas menyatakan pada 100 responden anak laki-laki dan perempuan mengalami pertumbuhan dan perubahan fisik laki-laki maupun perempuan yang sama pada masa remajanya (APA, 2002). Bahkan dalam perkembangan seksualitasnya remaja perempuan cenderung mengalami kematangan yang lebih cepat dibandingkan remaja lak-laki, sehingga hal tersebut dapat memungkinkan remaja perempuan pada usia 12-16 tahun lebih banyak yang tertarik dalam melakukan perilaku seksual yang berisiko tinggi (Karney et al., 2007). Baik remaja lakilaki maupun perempuan dengan tumbuh kembang yang sama akan mempunyai sisi perkembangan yang hampir sama yaitu perubahan fisik yang dialami oleh remaja lakilaki dan perempuan. Sehingga akan menimbulkan peluang yang sama untuk melakukan perilaku seksual berisiko tinggi (Friedman, 2010).

Umur termasuk faktor yang berpengaruh pada kegiatan seksual remaja karena seiring dengan pertambahan umur, perkembangan organ seksual semakin meningkat walaupun belum tentu pada perkembangan kedewasaannya (Hurlock, 1980). Sebagian besar remaja awal melakukan perilaku seksual berisiko (Sturgeon, 2008). Hal ini diakibatkan karena remaja mengalami masa transisi pubertas di kehidupannya untuk mencapai perkembangan remaja yang optimal tidak terfasilitasi dengan baik. Hasil penelitian ini sejalan dengan sebelumnya yang menyatakan bahwa terdapat hubungan usia dengan perilaku seksual berisiko tinggi (Nurhayati, 2013). Hal ini dikarenakan pubertas yang dialami oleh remaja berkaitan dengan faktor usia, semakin bertambah usia remaja maka masa pubertas akan terlewati melalui kemunculan tanda seks baik primer maupun sekunder (McMurray, 2007), sehingga akan mendorong remaja pada perilaku seksual berisiko tinggi dalam mencoba hubungan seksual.

Hidup dan tinggal dengan kedua orangtua memberi arti tersedianya kesempatan untuk mendapatkan dukungan, pengawasan, dan kontrol terhadap perilaku remaja dalam aspek kehidupan. Remaja yang tinggal dengan kedua orangtua kemungkinan kecil untuk melakukan perilaku seksual berisiko dibandingkan dengan remaja yang tinggal dengan salah satu orangtua atau tidak dengan keduanya (Santrock, 2003). Hasil penelitian ini menunjukkan siswa yang tinggal dengan kedua orangtua/orangtua lengkap lebih kecil kemungkinannya untuk melakukan perilaku seksual yang berisiko dibandingkan dengan tidak tinggal dengan keduanya. Hasil penelitian memperkuat penyataan tentang remaja dari keluarga utuh cenderung menunda insisiasi hubungan seksual sampai pada usia yang lebih matang (Sturgeon, 2008). Adanya anggapan remaja yang tidak tinggal bersama orangtua akan mendapat kontrol dan pengawasan yang tidak utuh dari orangtua dan keluarga sehingga menjadikan remaja semakin rentan terhadap pengaruh 
lingkungan dalam berperilaku, termasuk perilaku seksual. Namun, tidak semua remaja mengalami hal tersebut, tergantung dari kematangan, kepribadian dan motivasi dari remaja itu sendiri (Santrock, 2003).

Pengawasan orangtua berhubungan dengan struktur keluarga dalam beberapa hal. Perceraian yang dapat mengurangi jumlah orang dewasa di rumah tangga sehingga dapat mengurangi pengawasan (Friel dan Frial, 2001). Hasil penelitian ini bertolak belakang dengan hasil penelitian (Pilgrim, 2014) yang menyatakan remaja dengan struktur keluarga tidak utuh yaitu satu orangtua memiliki kemungkinan lebih besar dalam melakukan perilaku seksual berisiko. Namun, berbanding lurus dengan penelitian pada mahasiswa di salah satu perguruan tinggi di Jakarta yang menyatakan bahwa struktur keluarga yang utuh bukan faktor tunggal yang dapat menjamin remaja tidak melakukan perilaku seksual, karena terdapat faktor seperti hubungan orangtua dengan remaja, komunikasi dan sikap orangtua yang menabukan masalah seksualitas dan keterbukaan dari orangtua yang masih kurang (Sari, 2012).

Semakin muda usia pacaran, maka pengalaman berpacaran akan semakin banyak sehingga kemungkinan mengalami pengalaman seks lebih banyak yang pada akhirnya dapat mendorong munculnya perilaku seksual berisiko (Moore dan Rosenthal, 2006). Hal yang sama diungkapkan oleh Karney, usia remaja pertama kali pacaran sangat erat kaitannya dengan inisiasi seksual. Kebanyakan orang mengalami hubungan romantis mereka yang pertama selama masa remaja dan hubungan romantis biasanya mendahulukan pengalaman pertama remaja (Karney et al., 2007). Hasil penelitian ini tidak sejalan dengan penelitian (Putri, 2014) yang menyatakan bahwa tidak terdapat perbedaan signifikan proporsi perilaku seksual berisiko antara remaja yang usia pertama kali pacaran $<15$ tahun dengan yang $>15$ tahun.

Pada awal hubungan pacaran, remaja belum termotivasi untuk memenuhi kebutuhan seksualnya karena remaja kebanyakan masih merasa canggung dan belum terbiasa dengan pasangannya, namun setelah remaja mulai memperoleh kompetensi dalam berinteraksi dengan pasangannya, maka pemenuhan kelekatan dan kebutuhan seksual menjadi hal utama dalam hubungan (Santrock, 2003). Hubungan romantis pada remaja atau masa pacaran yang relatif tahan lama (bertahan selama lebih dari satu tahun) menunjukkan tingkat keintiman atau kedekatan yang lebih tinggi. Hal ini karena pertemuan semakin sering dan kedekatan yang semakin intim (Karney et al., 2007). Hasil yang sama diperoleh dalam penelitian Sari yang menunjukkan tidak ada hubungan yang bermakna antara lama berpacaran dengan perilaku seksual berisiko tinggi (Sari, 2012).

Hubungan Komunikasi Orangtua dengan Perilaku Seksual Remaja saat Berpacaran

Pada penelitian ini komunikasi dibedakan menjadi dua yaitu komunikasi secara umum dan komunikasi seksual dengan orangtua. Hasil penelitian ini menunjukkan adanya hubungan bermakna antara komunikasi secara umum dengan perilaku seksual remaja saat berpacaran. Hasil penelitian ini sejalan dengan hasil penelitian sebelumnya yang menyatakan bahwa komunikasi secara umum merupakan hal penting dalam membangun hubungan yang harmonis antara orangtua dengan remaja (Nurhayati, 2013). Komunikasi secara umum berpengaruh terhadap kualitas komunikasi, karena komunikasi yang bersifat disfungsional berhubungan dengan aktifnya remaja terhadap hubungan seksualnya (Miller et al., 1999). Berdasarkan nilai OR hasil penelitian ini sejalan dengan penelitian (Wang, 2009) yang mengemukakan bahwa komunikasi memiliki sifat keterbukaan dan kebebasan dalam menyelesaikan masalah sehingga akan mempengaruhi dalam pengambilan keputusan secara baik dibandingkan orangtua yang tidak melakukan hal tersebut. Komunikasi efektif yang terjadi diantara keluarga dan remaja dapat menjadi sarana diskusi untuk mengungkapkan perasaan dan problem yang dihadapi sehingga orangtua dapat memahami dan membantu masalah yang dihadapi remajanya (Friedman, 2010).

Kedua, hasil analisis komunikasi seksualitas dengan perilaku seksual saat berpacaran didapatkan persentase responden paling besar melakukan perilaku seksual berisiko adalah responden yang tidak melakukan komunikasi seksual dengan orangtuanya. Hasil penelitian ini sejalan dengan hasil penelitian (Putri, 2014), komunikasi seksual memiliki hubungan signifikan terhadap perilaku seksual remaja saat berpacaran, remaja yang berkomunikasi dengan orangtuanya masalah seks akan menurunkan perilaku 
seksual berisiko. Hubungan orangtua dengan remaja berfungsi sebagai faktor promotif yang dapat mengurangi keterlibatan awal dalam perilaku seksual berisiko. Orangtua hendaknya memberikan kenyamanan ketika berbicara mengenai seksual sehingga remaja menjadi percaya dan terbuka dalam membahas kesehatan reproduksi terutama perilaku seksual (Deptula et al., 2010). Orangtua hendaknya mulai berdiskusi mengenai kesehatan reproduksi dan perilaku seksual di awal perkembangan remaja karena dalam studi menyatakan berdiskusi masalah kesehatan reproduksi sejak awal akan memberikan kontribusi dalam memprediksi umur saat melakukan hubungan seksual pertama kali, jumlah pasangan dan kehamilan. Sehingga orangtua dapat mengantisipasi masalah perilaku seksual remajanya (Clawson \& Reese-Weber, 2003).

Hubungan Pola Asuh Orangtua dengan Perilaku Seksual Remaja saat Berpacaran

Pola asuh orangtua dapat mempengaruhi karakter remaja. Terdapat tiga Pola asuh yaitu authoritarian/otoriter, autoritatif/demokratis, dan permisif/longgar. Pola asuh authoritarian/otoriter dan permisif/longgar mempunyai dampak negatif terhadap remaja, sedangkan autoritatif/demokratis memberikan dampak positif karena remaja diberi kebebasan tetapi tetap bertanggungjawab (Santrock, 2003). Hasil Penelitian ini sejalan dengan hasil penelitian yang menunjukkan bahwa pola asuh memiliki hubungan yang signifikan dengan perilaku seksual berisiko tinggi saat berpacaran (Sari, 2012; Putri, 2014). Berdasarkan nilai OR menunjukkan bahwa remaja yang dididik dengan pola asuh authoritarian/otoriter dan permisif/longgar cenderung melakukan perilaku seksual berisiko tinggi saat berpacaran dibandingkan dengan pola asuh autoritatif/demokratis.

Remaja yang dididik dengan pola pengasuhan authoritarian, cenderung tidak kompeten, memilki keterampilan berkomunikasi yang buruk dan seringkali cemas terhadap perbandingan sosial. Hal ini dapat mempengaruhi remaja dalam perilaku seksual. Ketika mereka cemas tidak diterima lingkungan sosial, maka mereka berusaha untuk melakukan apa yang menjadi kebiasaan di lingkungan tersebut agar dapat diterima walaupun harus melakukan perilaku seksual seperti yang dilakukan oleh temannya. Pada pola asuh permisif yang lalai, dimana orangtua tidak terlibat dalam kehidupan remaja, hal ini memberikan kebebasan yang lebih besar bagi remaja dan kurangnya pengawasan remaja. Remaja juga Pengembangan Model Pelayanan Kesehatan Reproduksi Kesehatan Reproduksi Remaja cenderung memiliki pengendalian diri yang kurang. Hal ini dapat menyebabkan remaja terpengaruh oleh lingkungan sekitar dalam melakukan perbuatan berisiko termasuk perilaku seksual (Santrock, 2003).

\section{KESIMPULAN DAN SARAN}

Kesimpulan yang bisa ditarik dari penelitian ini adalah jenis kelamin dan umur berhubungan secara signifikan dengan perilaku seksual saat berpacaran pada siswa SMP di Sukorambi. Siswa perempuan lebih berisiko dibandingkan siswa laki-laki dalam berperilaku seksual berisiko tinggi. Demikian juga, siswa berumur $>15$ tahun lebih berisko dibandingkan remaja berumur $<15$ tahun untuk berperilaku seksual berisiko tinggi.

Pada aspek kehadiran orangtua, sebagian besar siswa mendapat pengasuhan secara autoritatif dan berkomunikasi secara fungsional dengan orangtuanya, namun tidak mengkomunikasikan tentang seksualitas.

Komunikasi dan pola asuh memiliki hubungan yang signifikan dengan perilaku seksual siswa saat berpacaran. Siswa yang melakukan komunikasi bersifat disfungsional atau tidak melakukan komunikasi seksual dengan orang orangtuanya lebih berisiko untuk melakukan perilaku seksual berisiko tinggi. Demikian juga siswa yang mendapat pola asuh autoritarian/otoriter dan permisif/longgar lebih berisiko untuk melakukan perilaku seksual berisiko tinggi dibandingkan remaja yang mendapatkan pola asuh autoritatif/demokratis.

Hasil penelitian ini merekomendasikan kepada Dinas Pemberdayaan Perempuan, Perlindungan Anak dan Keluarga Berencana (DP3AKB) Kabupaten Jember untuk memberikan pendidikan kepada orang tua tentang komunikasi dan pola asuh yang efektif melalui kegiatan Bina Keluarga Remaja (BKR).

\section{DAFTAR RUJUKAN}

1] Santrock J., W. (2003) Adolescent: Perkembangan Remaja. Jakarta: Erlangga.

2] Badan Pusat Statistik, Badan Koordinasi Keluarga Berencana Nasional, Departemen Kesehatan, Macro International. (2013) 
Survei Demografi dan Kesehatan Indonesia 2012 Kesehatan Reproduksi Remaja. Sdki. Jakarta: Badan Pusat Statistik Badan Koordinasi Keluarga Berencana Nasional Departemen Kesehatan Macro International; 16 p.

3] Kusumawardani N., Rachmalina, Wiryawan Y., Anwar A., Handayani K., Mubasyiroh R., et al. (2015) Perilaku Berisiko Kesehatan pada Pelajar SMP dan SMA di Indonesia. Badan Litbangkes Kementrian Kesehatan RI. Jakarta: Puslitbang Upaya Kesehatan Masyarakat Badan Litbangkes Kementerian Kesehatan RI; 1-116 p. Available from: http://www.who.int/ncds/surveillance/gshs/ GSHS_2015_Indonesia_Report_Bahasa.pd f?ua $=1$

4] Sarwono S., W. (2006) Psikologi Remaja. Jakarta: Rajawali.

5] Suwandono A. (2002) Pengembangan Model Pelayanan Kesehatan Reproduksi Remaja. Jakarta: Badan Penelitian dan Pengembangan Kesehatan Republik Indonesia.

6] Suwarni L. (2009) Monitoring Parental dan Perilaku Teman Sebaya Terhadap Perilaku Seksual Remaja SMA Di Kota Pontianak. Indones J Heal Promot. 4(2):127-33.

7] Rokhmah D. (2014) Implikasi Mobilitas Penduduk Dan Gaya Hidup Seksual Terhadap Penularan Hiv/Aids. KESMAS J Kesehat Masy. 9(2):183-90.

8] Nurhayati. (2013) Hubungan Kekuatan Keluarga Terhadap Perilaku Seksual Berisiko Pada Remaja di Wilayah Desa Tridaya Sakti Kecamatan Tambun Selatan Kabupaten Bekasi. J Keperawatan Komunitas. 1(2):122-9.

9] Association A., P. (2002) Developing Adolescent: A Reference for Professionals. Vol. 6. Washington, DC: American Psychological Association;

10] Karney B. R., Beckett M. K, Collins R. L, Shaw R. (2007) Adolescent Romantic Relationships as Precursors of Healthy Adult Marriages A Review of Theory, Research, and Programs. Santa Monica United States: RAND Corporation.
11] Friedman M. M. (2010) Buku Ajar Keperawatan Keluarga: Riset, Teori dan Praktik. Jakarta: EGC Penerbit Kedokteran.

12] Hurlock E. B. (1980) Psikologi Perkembangan (Suatu Pendekatan sepanjang Rentang Kehidupan) (5th ed.). Jakarta: Erlangga.

13] McMurray A. (2007) Community Health and wellness: Sosio, Ecological, Approach Australia. Sidney: Mosby Elsevier, cop.

14] Sturgeon W. (2008) The Relationship Between Family Structure and Adolescent Sexual Activity. Spec Rep | Fam. 1(1):360. Available from: www.familyfacts.org\%0ANothing

15] Friel E. C. D, Frial F. (2001) Adolescent Sexuality: Disentangling the Effects of Family Structure and Family Context. J Married Fam. 63(3):669-81.

16] Pilgrim N. A, Ahmed S, Gray R. H, Sekasanvu J, Lutalo T, Nalugoda F, et al. (2014) Family structure effects on early sexual debut among adolescent girls in Rakai, Uganda. Vulnerable Child Youth Stud. 9(3):193-205. Available from: http://dx.doi.org/10.1080/17450128.2013.8 42027

17] Sari S. N. (2012) Perilaku Seksual dan Faktor yang Berhubungan pada Mahasiswa S1 Reguler Fakultas $X$ Universitas Indonesia. Skripsi Universitas Indonesia. Jakarta: Fakultas Kesehatan Masyarakat Universitas Indonesia. 1-195 p. Available from: http://lib.ui.ac.id/file?file=digital/2031561 8-S_Suci Nofita Sari.pdf

18] Moore S, Rosenthal D. (2006) Sexuality in Adolescence: Current Trend. New York: Routledge.

19] Putri B. D. (2014) Peran Faktor Keluarga Dan Karakteristik Remaja Terhadap Perilaku Seksual Pranikah. J Biometrika dan Kependud [Internet]. 3(1):8-19. Available from: http://journal.unair.ac.id/filerPDF/biometri kfde8cc6696full.pdf

20] Miller KS, Forehand R, Kotchick BA. (1999) Adolescent Sexual Behavior in Two Ethnic Minority Samples: The Role of 
Family Variables. J Marriage Fam. 61(1):85-98.

21] Wang Z. (2009) Parent-Adolescent Communication and Sexual Risk-Taking Behaviours of Adolescents. (December).

22] Deptula DP, Henry DB, Schoeny ME. (2010) How can parents make a difference? Longitudinal associations with adolescent sexual behavior. J Fam Psychol. 24(6):731-9.

23] Clawson CL, Reese-Weber M. (2003) The amount and timing of parent-adolescent sexual communication as predictors of late adolescent sexual risk-taking behaviors. $\mathrm{J}$ Sex Res. 40(3):256-65. 